\title{
FOR YOUR BOOKSHELVES
}

All figures given in dollars are in U.S. funds unless indicated otherwise. Symbols listed are as follows: $C=$ Cloth, $P=$ Paper, $F=$ Flexicover, $H=$ Hardcover, $S=$ Softcover. Bold figures in brackets indicate order address number (see Order Address List, below).

NEW BOOKS

hined, F. and Nimond, D.C. FIELD MAPPING FOR GEOLOG Y STUDENTS. Allen \& Unwin, 1983, $71 \mathrm{p}$., f 3.95 . (3)

Ahnert, F., Rohdenburg, H. and Gemmel, A. CONTRIBUTIONS TO TROPICAL GEOMORPHOLOGY (Cast-Arica, Brazil, Central- and West-Africa). Catena Verlag, 1982, 140p., price not listed. Avalabie: from Catena verlag. Rrockenblick 8 , 3302 Cremlingen 4, F.R.G.

virens. L.h. IONIZATION POTENTIALS. Pergamon, $1983,10 \%$ p. $\$ 29.50 /$ f16.50. (24)

inderson. $O$ Roger. RADIOLARIA. Springer-Verlag, $1983,35 \%$. \$59. (29)

irmstead. H.C.H. GEOTHERMAL ENERGY, 2nd ed. Nethue, , 1983, 357p., \$49.50. (21)

than, $Y$, and Feller, C. APPLICATIONS DE LA PEDOLOKIE A LA GEOTECHNIQUE ROUTIERE. Exemple due Sénégal. BRGM Document no. 56, $1983.8 . \mathrm{F} .100 \mathrm{FF}$. (9)

Itterton, U.P. and Gribble, C.D. (eds.) MIGMATITES, MELTING AND METAMORPHISM. Birkhauser, 1983,\$39.95. (5)

ugustithis. S.S. (ed.) LEACHING AND DIFFUSION IN ROCKS AND THEIR WEATHERING PRODUCTS. Theophrastus, 1983, 560p..\$35 (C). (31)

Hgustithis. 5.S. (ed.) THE SIGNIFICANCE OF TRACE ELEMENTS IN SOLVING PETROGENETIC PROBLEMS \& CONTROVERSIES. Theophrastus, 1983,91 p. $\$ 55$. (31)

Bach. W, and Letolle, R. (eds.) GEOCHEMISTRY OF GROUNIWATER. Developments in Water Science, 16. Elsovier, 1983, 370p., price not listed. (I4)

Barbier. Vaurice G. THE MINI-SOSIE METHOD. IHRDC. $1983,96 \mathrm{p}, \$ 28$ (C). (18)

Bendall, D.S. (ed.) EVOLUTION FROM MOLECULES TO MEN. Cambridge, 1983,608 p., $\$ 29.95 / \mathrm{f} 18$. (II)

Bender, $\because$ GEOLOGY OF BURMA; Heitrage zur Regional n Geologie der Erde, v. 16. Borntraeger, $1983, \$ \$ 4.28(H)$. (15)

Kergeron, C.. Dehays, H., and Pointet. T. REMONTEES DES NAPPES D'EAU SOUTERRAINE. CAUSES ET EFFETS. BRGM Document no. 60 . 1483.50\%, $70 \mathrm{FF}$. (9)

herton, Y. and Le Berre, P. GUIDE DE PROSPECTION DES MATERIAUX DE CARRIERE. BRGM norumert no. 5, 1983, 160p., 80F F. (9)

Bignot. Girard. LES MICROFOSSILES: les différents groupes - exploitation paléobiologique et géologique. Dnod, 1982, 212, 75FF. Available from Dunot, 17 rue Rémy-Dumoncel, B.P. 50, 75661 Paris Cidex 14, France.

irabb, Lar: E. (ed.) STUDIES IN TERTIARY STRATIGRAPHY OF THE CALIFORNIA COAST RANGES, USGS Professional Paper 1213. USGS, 1983.93\%. price not listed. (30)

TraIT, A. FORMATION OF PLANETARY SYSTEMS. Text of lectures presented at the CNES 1980 simmer school held at Grasse, France. In English. 1982. $896 \mathrm{p} ., 295 \mathrm{FF}$. Available from Cepadues Edi- tions, 111 rue Nicolas-Vauquelin, 31100 Toulouse, France.

Brooks, J. (ed.) PETROLEUM GEOCHEMISTRY AND EXPLORATION OF EUROPE. Geological Society Special Publication No. 11. Blackwell, 1983, 400p. $\$ 60 /$ f 35. (6)

Cahen, L., Snelling, N.J., Delhal, J., Vail, J.R., Bonhomme, M. and Ledent, D. THE GEOCHRONOLOGY AND EVOLUTION OF AFRICA. Oxford 1983, 750p., \$213.75. (23)

Carozzi, Abert V. MODELOS DEPOSICIONALES CARBONATICOS. Argentine Geological Associa tion, Series B, no. 11, vols. 1 and 2. 1983, 303p. $\$ 20$. In Spanish. Available from F. García Cam beiro, Cochabamba 244,1150 Bucnos Aires, Argen tina.

Cas, Ray. PALAEOGEOGRAPHIC AND TECTONIC DEVELOPMENT OF THE LACHLAN FOLD BELT SOUTHEASTERN AUSTRALIA. Geological Society Australia Spccial Publication 10. 1983, 104p. $\$ 17.50$ Aus. Available from Geological Society of Australia, 10 Martin Place, Sydney, N.S.W. 2000, Australia.

Chapman, P.F. and Roberts, F. METAL RESOURCES AND ENERGY. Butterworth, 1983, 238p., f 20 (C) $f: 1(P)$. (10)

Charig, Alan. A NEW LOOK AT THE DINOSAURS, Facts on File, 1983, 160p., \$15.95. Available from Facts on File, Inc., 460 Park Ave. S., New York, NY 10016 , U.S.A.

Cook, Frederick, A., Brown, Larry D., Kaufman, Sidney and Oliver, Jack E. THE COCORP SEISMIC REFLECTION TRAVERSE ACROSS THE SOUTH ERN APPALACHIANS. AAPG, 1983, 60p., \$18 (AAPG-SEPM members); $\$ 24$ (others). (1)

Cooke, R.U. et al. URBAN GEOMORPHOLOGY IN DRYLANDS. Oxford, 1982, 324p., \$32. (23)

Cuff, W.R. and Tomczak, M., Jr. (eds.) SYNTHESIS AND MODELLING OF INTERMITTENT ESTUAR IES, Lecture Notes on Coastal and Estuarine Studies. Springer-Verlag, 1983, 302p., \$22.50. (29)

Das, B.M. ADVANCED SOIL MECHANICS. MCGrawHill, 1983, 511 p., \$34.95. (20)

Delany, F.M. and Rast, N. (eds.) PROFILES OF OROGENIC BELTS. AGU, 1983, 320p., \$36. (4)

Dietrich, R.V. and Wicander, R. MINERALS, ROCKS, AND FOSSILS. John Wiley Self-Teaching Guides, 1983, 212p., \$9.95. (36)

Dodd, Robert T. METEORITES. Cambridge, 1982 , 368p., \$69.50/千 35 (H). (11)

Drabet, Mushkatel and Kliyanek. EARTHQUAKE MITIGATION POLICY: The experience of two states. Institute of Behavioral Science, 1983, $\$ 8$ (P). Available from Environment \& Behavior Program, Campus Box 482, University of Colorado, Boulder, CO 80309 , U.S.A.

Dregne, H.E. DESERTIFICATION OF ARID LANDS, Harwood, 1983, 254p., \$33.25 (H). Available from Harwood Academic Publishers, P.O. Box 786, Cooper Station, New York, NY 10276, U.S.A.; or 42 Williarn IV Street, London WC2N 4DE, U.K.

Earll, R. and Erwin, D.G. SUBLITTORAL ECOLOGY.
Oxford, 1983, 200p., \$51.50. (23)

Eichert, B.S. et al. (eds.) METHODS OF HYDROLOGICAL COMPUTATIONS FOR WATER PROJECTS. Studies and Reports in Hydrology No. 38. Unesco, 1982, 124p., 65FF (in France). Available from Unesco, 7 Place de Fontenoy, 75700, Paris, France.

Fabre, J. (ed.) AFRIQUE DE L'OUEST/WEST AFRICA. Lexique Stratigraphique International Vol. 10, Nouvelle Series No. 1. Pergamon, 1983 , 426p., $\$ 74.75(\mathrm{H})$. Text in French or English. (24)

Farmer, I.W. ENGINEERING BEHAVIOUR OF ROCKS. Methuen, 1983, 224p., \$43(H); \$19.95(P). (2I)

Faul, Henry and Faul, Carol. IT BEGAN WITH A STONE. Wiley, 1983, 272p., \$38.95 (C); \$23.95 (P). (36)

Fedotov, S.A and Markhinin, Yo.K. (eds.) THE GREAT TOLBACHIK FISSURE ERUPTION. Translated from Russian by J.E. Agrell et al. Cambridge, 1983, 34 lp., \$69.50/f 35. (11)

Fox, K.F., Jr. MELANGES AND THEIR BEARING ON LATE MESOZOIC AND TERTIARY SUBDUCTION AND INTERPLATE TRANSLATION AT THE WEST EDGE OF THE NORTH AMERICAN PLATE. USGS Professional Paper P1198. 1983, 40p., \$4.75. Available from U.S. Geological Survey, $582 \mathrm{Na}$ tional Center, Reston, VA 22092, U.S.A.

Fry, Norman. THE FIELD DESCRIPTION OF METAMORPHIC ROCKS. Wiley, 1983, 170p., \$12.95. (36)

Fremd, V.M. and Shebalin, N.V. (eds.) RESEARCH OF SEISMICITY IN SEISMIC ZONES OF LESS ACTIVITY (Central Cuba). In Russian with English abstracts. Nauka, 1983, 134p. Available from the Soviet Geophysical Committee on a book-exchange basis. (28)

Fuchs, K. et al. (eds.) PLATEAu UPLIFT, The Rhenish Shield. Springer-Verlag, 1983, $41 \mathrm{Ip.}$ $\$ 49.50$ (C). (29)

Gade, Herman G., Edwards, Anton and Svendsen, Harald. COASTAL OCEANOGRAPHY. PlenUm, 1983 , 5900., $\$ 79.50$ (U.S.A., Canada); $\$ 95.40$ (elsewhere). (25)

Galloway, W.E. and Hobday, David K. TERRIGENOUS CLASTIC DEPOSITIONAL SYSTEMS. Springer-Verlag, 1983, 416p., \$39 (C). (29)

GEOTECHNICAL PRACTICE IN OFFSHORE ENGINEERING. Telford, 1983, 640p., f 41.50. (32)

Glass, Billy P. INTRODUCTION TO PLANETARY GEOLOGY. Cambridge, 1983, 469p., \$29.95/ 18. (11)

Govett, M.H. and Larsen, J. (compilers) THE WORLD ALUMINIUM INDUSTRY, vol. II. Australian Mineral Economics Pty., 1982, 349p., \$265. Available from Australian Mineral Economics Pty., Ltd., 17th Floor, I York Street, Sydncy, N.S.W. 2000, Australia.

Grosswald, M.G. ICE SHEETS OF THE CONTINENTAL SHELVES. Nauka, 1983, 216p. In Russian. Available on a book-exchange basis from the Soviet Geophysical Committee. (28) 
Habib, Pierrc. AN OUTLINE OF SOIL AND ROCK MECHANICS. Translated from French by Bronwen A. Rees. Cambridge, 1983, 149p., \$29.95/令 $15(\mathrm{H})$; $\$ 11.95 /$ f $5.95(\mathrm{P})$. (1 I)

Hallam, A. GREAT GEOLOGICAL CONTROVERS IES. Oxford, 1983, 182p., \$35 (C); \$14.95 (P). (23)

Hallberg, Rolf (ed.) ENVIRONMENTAL BIOGEOCHEMISTRY. Ecological Bulletin no. 35 Swedish Research Council, 1983, 576p., $\$ 37 /$ Sk 260. Available from The Publishing House, Swcdish Research Councils, Box 6710. S-11385 Stockholm, Sweden.

Hardage, Bob A. VERTICAL SEISMIC PROFILING, Part A: Principles. Geophysical Press, 1983, \$48 (H). (17)

Hatcher, Robert D., Jr. et al. (eds.) TECTONICS AND GEOPHYSICS OF MOUNTAAIN CHAINS. GSA Memojr 158, 1983, 224p., \$42.50 (H). (16)

Hawkesworth, C.J. and Norry, M.J. (eds.) CONTINENTAL BASALTS AND MANTLE XENOLITHS. Birkhauser, 1983, \$19.95 (P) (5)

Hirdes, $W$. and Sauger, R. THE PROTEROZOIC KIMBERLEY REEF PLACER IN THE EVANDER GOLDFIELD WITWATERSRAND, SOUTH AFRICA, Monograph Series on Mineral Deposits, no. 20. Borntraeger, 1983, $\$ 33.54$ (P). (15)

Hsü, Kenneth J. A VOYAGE OF THE GLOMAR CHALLENGER. Princeton, 1983, 220p., \$17.95. (26)

Kanai, Kiyoshi. ENGINEERING SEISMOLOGY. University of Tokyo, 1983, $\$ 34.50(\mathrm{H}) .(12,33)$

Kearey, P. and Brooks, M. AN INTRODUCTION TO GEOPHYSICAL SURVEYING. Blackwell, 1983, 360p., f 10.50 . (6)

Kennett, B.L.N. SEISMIC WAVE PROPAGATION IN STRATIFIED MEDIA. Cambridge, 1983, 350p., $\$ 59.50 /$ \& 30 . (11)

Kennett, James P. and Srinivasan, M.S. NEOGENE PLANKTONIC FORAMINIFERA. Hutchinson Ross, 1983,288 p., $\$ 36.50(\mathrm{H})$. (34)

Ketchum, Bostwick H. (cd.) ESTUARIES AND ENCLOSED SEAS. Ecosystems of the World 26. Elsevier, 1983, 500p., \$170.25. (14)

King, E.A., Jr. (ed.) CHONDRULES AND THEIR ORIGINS. LPI, $1983,375 \mathrm{p} ., \$ 30$ (plus $\$ 3$ shipping and handling). (19)

Kinghorn, Robert Richard Francis. AN INTRODUCTION TO THE PHYSICS AND CHEMISTRY OF PETROLEUM. Wiley, 1983, 300p., \$39.95. (36)

Kirbos, D.P. et al. (eds.) AUTOMATIC COLLECTION AND PROCESSING OF SEISMOLOGICAL INFORMATION. Radio i Svyaz, 1983, 88p. In Russian with English abstracts. Available on a book-exchange basis from the Soviet Geophysical Committec. (28)

Kobayashi, Toriyama, and Hashimoto (eds.) GEOLOGY AND PALAEONTOLOGY OF SOUTHEAST ASIA, vol. 24. University of Tokyo Press, 1983 , $\$ 59.5(\mathrm{H}) .(12,33)$

Krass, M.S. MATHEMATICAL THEORY OF GLACIOMECHANICS. Moscow, 1983, 142p. In Russian. Available on a book-exchange basis from the Soviet Geophysical Committee. (28)

Lacy, Willard C. (ed.) MINING GEOLOGY. Benchmark Papers in Gcology, vol. 69, Hutchinson Ross, $1983,466 \mathrm{p} ., \$ 58$. (34)

Lehman, John P. (ed.) HAZARDOUS WASTE DISPOSAL. Plenum, 1983, 400p., \$49.50 (U.S.A., Canada); $\$ 59.40$ (elsewhere). (25)

Lehmann, 1. and Hillmer, G. FOSSIL INVERTEBRATES. Translated from German by Janine Lcttau. Cambridge, 1983, 368p., $\$ 39.50 / \mathbf{f} 20(\mathrm{H})$; $\$ 13.95 / \mathbf{f} 7.50(\mathrm{P})$. (11)

Lewis, Douglas $W$. PRACTICAL SEDIMENTOLOGY. Van Nostrand Reinhold, 1983, 288p., \$22.95. (34) Lewy, Zeev. UPPER COLLOVIAN AMMONITES AND
MIDDLE JURASSIC GEOLOGICAL HISTORY OF THE MIDDLE EAST. Geological Survey of Israel, 1983,55 . plus 8 plates, $\$ 10$ (P). Available from the Geological Survey of Israel-Library, 30 MalkheIsrael Strect, Jerusajem, Israel.

Longhi, J. and Ryder, G. (eds.) Workshop on PRISTINE HIGHLANDS ROCKS AND THE EARLY HISTORY OF THE MOON. LPI, 1983, 92p., \$3 (U.S.A.); \$7 (elsewhere, airmail). (19)

MacDonaid, E.H. ALLUVIAL MINING. Methuen, 1983, 580p., $\$ 79.95(\mathrm{H})$. (21)

MacDonald, Gordon A., Abbot, Agatin T., and Peterson, Frank L. VOLCANOES IN THE SEA: The Geology of Hawaii. (2nd ed.) University of Hawaii Press, 517p., 529.95. Available from University of Hawail Press, Honolulu, HA 96822, U.S.A.

McDonald, John A., Gardner, G.H.F. and Hilterman, F.J. (eds.) SEISMIC STUDIES IN PHYSICAL MODELING. IHRDC, $1983,256 \mathrm{p}$, $\$ 54(\mathrm{C})$. (18)

McPhee, John. IN SUSPECT TERRAIN. Farrar, Straus \& Giroux, 1983, \$12.95(H). Available from Farrar Straus \& Giroux, Inc., 19 Union Square West, New York, NY 10003 , U.S.A.

Mendel, Jerry M. OPTIMAL SEISMIC DECONVOLUTION. Academic, 1983, 272p., \$37.50. (2)

Miller, David M. et al. (eds.) TECTONIC AND STRATIGRAPHIC STÜDIES IN THE EASTERN GREAT BASIN. GSA Memoir 157, 1983, 327p., \$37 (H). (16)

MINERAL RESOURCES OF THE ARAB COUNTRIES. British Sulphur Corporation, 1983, 100p., $\$ 130(\mathrm{H})$. (2I)

MINERALS YEARBOOK: metals and minerals. U.S. Bureau of Mincs, 1982, 968p., \$17. (30)

Molnia, B.F. (ed.). GLACIAL-MARINE SEDIMENTATION. Plenum, 1983, 844p., \$65 (U.S.A.); \$78 (elsewhere). (25)

Morrison, R.D. GROUND WATER MONITORING TECHNOLOGY: Procedures, Equipment and Application. Timco, 1983, 111p., $\$ 33$. Available from Timco Mfg., Prairie du Sac, WI 53578, U.S.A.

Nriagu, Jerome O. LEAD AND LEAD POISONING IN ANTIQUITY. Wiley, 1983, \$49.95. (36)

Perrodon, Nlain. DYNAMICS OF OIL AND GAS ACCUMULATIONS. Elf Aquitaine, 1983, 368p., $\$ 32 / 240 \mathrm{FF}$. Available from Elf Aquitaine, Dorumentation Centre Micoulau, 64018 Pau, France.

Petersen, K.K. OIL SHALE: Environmental Challenges 13. Colorado School of Mines, 1983, \$20 (H). Available from Colorado School of Mines Press, Publications Center, Golden, CO 80401 , U.S.A.

Petri, S. and Fúlfaro, V.J. GEOLOGIA DO BRASIL (Fanerozóico). T.A. Quieroz, 1983, 631p., price not listed. Available from T.A. Quieroz, Editor Ltda, Rua Joaquim Floriano $733-4^{\circ}, 04534$ Sño Paulo SP, Brasil.

Pieuchot, Maurice. SEISMIC INSTRUMENTATION. Geophysical Press, 1983, \$48 (H). (17)

Pinneker, E.V. (ed.). GENERAL HYDROGEOLOGY. Translated from Russian by D.E. Howard. Cambridge, 1983, 141 p., $\$ 44.50 / \mathrm{f} 22.50$. (11)

Pirson, Sylvain J. GEOLOGIC WELL LOG ANALYSIS. Gulf, 1983, 47.5p., \$29.95. Available from Gulf Publishing Co., P.O. Box 2608, Houston, TX 77001 , U.S.A.)

Pye, V.I., Patrick, R., and Quarles, J. GROUNDWATER CONTAMINATION IN THE UNITED STATES. University of Pennsylvania Press, 1983, $307 \mathrm{p}$. \$14.95. Available from the University of Pennsylvania Press, 3933 Walnut Street, Philadelphia, PA 19104, U.S.A.

Read, Peter G. GEMMOLOGICAL INSTRUMENTS. Butterworth, 1983, 328p., \$39.95. (10)

Rice, Dudley D. and Gauticr, Donald L. PATTERNS OF SEDIMENTATION DIAGENESIS, AND HYDRO-
CARBON ACCUMULATION IN CRETACEOUS ROCKS OF THE ROCKY MOUNTAINS. Lecture Notes for SEPM Short Course No. 11. SEPM. 1983. 317 p., \$16 (SEPM members), \$20 (others). Vailable from SEPM, P.O. Box 4756, Tulsa, OK 7:159-0756. U.S.A.

Riva, Joseph P., Jr. WORLD PETROLEUM RESOURCES AND RESERVES. Westvim, 1983. 355 p. $\$ 45$. (35)

Robin, Gordon de Q. (ed.). THE CLIMATIC RECORD IN POLAR ICE SHEETS. Cambridge, 1983. 212p. $\$ 59.50 / £ 32.50$. (11)

Robinson, Enders A. SEISMIC INVERSION AND DECONvoluTION, Part A: Classical nethods. Geophysical Pres5, 1983, \$48(H). (I7)

Robison, R.A. (ed.) TREATISE ON INVERTEBRATE PALEONTOLOGY, Part G(1), Bryozoa, Reviscd, vol. 1. GSA, $1983,626 \mathrm{p} ., \$ 48$. (16)

Roddick, ].A. (ed.) CIRCUM-PACIFIC PLUTONIC TERRANES. GSA Memoir 159, 1983, 36p. \$42 (H). (16)

Rossmanith, H.P., Schmidt, R.A., Fourney, W.L. Cieary, M.P., Ouchterlony, F. and Ingraffea, A.R. ROCK FRACTURE MECHANICS. Springer-Verlag. 1983, 300p., \$34 (C). (29)

Rupke, Nicolaas A. THE GREAT CHAIN OF HISTORY. Oxford, 1983, 400p., \$71.25. (23)

Savage, Donald E. and Russel], Donald [. MAM MALIAN PALEOFAUNAS OF THE WORLD. Addi son-Wesley, 1983, 432p., \$79.95. Available from Addison-Wesley Publishing Co. Inc.. Jacob Way, Reading MA 01867, U.S.A.

Saxena, S.K. (ed.) KINETICS AND EQUILIBRIUM IN MINERAL REACTIONS. Advances in Physical Geochemistry vol. 3. Springer-Verlag, 1483. 273p. $\$ 39.80$. (29)

Scanvic, J.-P. UTILISATION DE LA TELEDETECTION DANS LES SCIENCES DE LA TERRE. BRGM Document no. 7, 1983, 160p., 90FF. (9)

Serruya, Colctte and Pollingher, Utsa. LAKES OF THE WARM BELT. Cambridge, 1983, $581 \mathrm{p}$. $\$ 89.50 / £ 45$. (11)

Servant, $M$. SEQUENCES CONTINENTALES ET VARIATIONS CLIMATIQUES: évolution du bassin du Tchad au Cénozoîque supérieur. BRGM Travaux et Documents no. 159, 1983,573p., 200FF. (9)

Sheldon, Richard P. SEARCH FOR AND DEVELOPMENT OF UNDISCOVERED PHOSPHATE RESOURCES IN SOUTHEAST ASIA. Resource Sys-
tems Institute, 1983, 55p., price not listed. Available from The East-West Center, 1777 East-West Road, Honolulu, HA 96848 , U.S.A.

Shumsky, P.A. and Krass, M.S. DYNAMICS AND THERMICS OF GLACIERS. Nauka, 1983, 86p. In Russian. Available on a book-exchange basis from the Soviet Geophysical Committee. (28)

Simkin, Tom and Fiske, Richard, S. KRAKATAU 1883 - The Volcanic Eruption and its Effects. Smithsonian, 1983, 470p., \$15 (P). Availuble from Smithsonian Institution Press, P.O. Box 1579 ,
Washington, DC 20013 , U.S.A.

Sloan, D.A. MINE MANAGEMENT. Methien, 1983. $416 \mathrm{p} ., \$ 49.95(\mathrm{H})$. (21)

Soward, A.M. (ed.) STELLAR AND PLANETARY MAGNETISM. vol. 1, The fluid mechanics of astro-
physics and geophysics. Gordon and Breach. 1983 , physics and geophysics. Gordon and Brearh. 1983 ,
$375 \mathrm{p} ., \$ 69.50$. Avalable from Gordon and Breach Science Publishers, Inc., I Park Avenue, New York. NY 10016 , U.S.A.

Stearns, Harold T. MEMOIRS OF A GEOLOGIST: From Poverty Peak to Piggery Gulch. Hawaii Institute of Geophysics, 1983, \$8.50 (H) plus \$1.50 postage. Available from Hawail Institute of Cico physics, University of Hawaii at Manoa. 2525 Correa Road. Honolulu, HI 96822, U.S.A. 
Stewart, Wilson N. PALEOBOTANY AND THE EVOLUTION OF PLANTS. Cambridge, 1983, 405p. $\$ 29.95(\mathrm{H})$. (11)

Stowe, K. OCEAN SCIENCE. 2nd ed. Wiley, 1983 , $673 \mathrm{p} ., \$ 27.95$. (36)

A STUDY OF THE ISOLATION SYSTEM FOR GEOLOGIC DISPOSAL OF RADIOACTIVE WASTES Board on Radioactive Waste Management, 1983 , 356p. \$24.95. Available from National Academy Press, 2101 Constitution Avenue NW, Washington, DC 20418 , U.S.A.

Sündermann, J. and Lenz, w. (eds.) NORTH SEA DYNAMICS. Springer-Verlag, 1983, 693p., \$41. (29)

Tarling, D.H. PALAEOMAGNETISM. Methuen, 1983 320 ., $\$ 55(\mathrm{H}) ; \$ 29.50(\mathrm{P})$. (21)

Tevesz, Michael J.S. and McCall, Peter L. (eds.) BIOTIC INTERACTIONS IN RECENT AND FOSSIL BENTHIC COMMUNITIES. Topics in Geobiology vol. 3. Plenum, 1983, 856p., $\$ 95$ (U.S.A., Canada); $\$ 114$ (elsewhere). (25)

Thiery, D., Vandenbeusch, M., Vaubourg, P. INTERPRETATION DES POMPAGES D'ESSAI EN MILIEU FISSURE AQUIFERE. BRGM Document no. 57 , 1983, 53p., 80FF. (9)

Toksoz, M. Nafi. VERTICAL SEISMIC PROFILING, Part B: Advanced concepts. Geophysical Press, 1983, $\$ 48(\mathrm{H})$. (17)

Trudgill, Stephen T. WEATHERING AND EROSION. Butterworth, 1983, 192p., \$12.50 (P). (10)

VanLandingham, Sam L. (ed.). ECONOMIC EVALUATION OF MINERAL PROPERTY. Benchmark papers in Geology, vol. 67. Hutchinson Ross, 1983 400p., \$48.50 (H). (34)

Verma, Rajni K. ELECTROMAGNETIC SOUNDING INTERPRETATION DATA OVER THREE-LAYER EARTH. Plenum, 1982, Z-volume set, 900p., \$165 (U.S.A., Canada); \$198 (elsewhere). (25)

Vvedenskaya, A.V. and Solovyeva, O.N. (eds.) INTERPRETATION OF SEISMIC OBSERVATIONS Moscow, 1983, 136p. In Russian with English abstracts. Available from the Soviet Geophysical Committee. (28)

Wanless, R.M. FINANCE FOR MINE MANAGEMENT Methuen, 1983, 192p., \$30 (H). (21)

Watkins, J.S. and Drake, C.L. CONTINENTAL MARGIN GEOLOGY. AAPG Memoir 34, 1983, $\$ 38$ (AAPG members); $\$ 46$ (others). (1)

Webster, Robert. GEMS. Their sources, descriptions, and identification. Revised by $\mathrm{BW}$. Anderson. Butterworth, 1983, 1006 p., \$79.95. (10)

Wels, Tom. THE RECUAY MINING SCHOOL, PERU. 1983, I1p., £1.50. Available from Intermediate Technology Industrial Services, Myson House, Railway Terrace, Rugby CV21 3HT, U.K.

White, J.E, UNDERGROUND SOUND: APPLICATION OF SEISMIC WAVES. Elsevier, 1983, 254p., $\$ 59.50$. (14)

Woakes, Michael and Carman, John S. (eds.) AGID GUIDE TO MINERAL RESOURCES DEVELOPMENT. AGID Report Series no, 10, 1983, 504p., $\$ 25 ; \$ 18.50$ (members in developed countries); $\$ 15$ (members in less developed countries). Available from AGID, Asian Institute of Technology, P.O. Box 2754, Bangkok 10501, Thailand.

Wong, C.S. et al. (eds.) TRACE METALS IN SEA WATER. Plenum, 1983, 934p., \$115 (U.S.A., Canada); $\$ 138$ (elsewhere). (25)

Wolff, Diane D. and Parsons, Michael L. PATTERN RECOGITION APPROACH TO DATA INTERPRETATION . Plenum, 1983, 225p., \$29.50 (U.S.A. Canada); $\$ 35.40$ (elsewhere). (25)

PROCEEDINGS OF SYMPOSIA

Agnew, Allen F. (ed.) INTERNATIONAL MINERALS:
A National Perspective. AAAS Selected Symposium $90,1983,164$ p., $\$ 20 .(35)$

Bender, F. (ed.) NEW PATHS TO MINERAL EXPLORATION. Proceedings of 3rd International Symposium held October 1982, Hannover. Schweizer bart'sche Verlagsbuchhandlung, 1983, \$24.94 (P). (27)

Bott, Martin H.P. et al. (eds.) STRUCTURE AND DEVELOPMENT OF THE GREENLANDSCOTLAND RIDGE. Proceedings of an Institute held in Bressanone, Italy. NATO Conference Series IV, vol. 8. Plenum, 1983, 696p., \$85 (U.S.A., Canada); $\$ 102$ (eisewhere). (25)

Bull, $C$. and Lipschutz, M.E. WORKSHOP ON ANTARCTIC GLACIOLOGY AND METEORITES. LPI, 1982, 57p., \$3 (U.S.A.); \$6 (others, air mail). (19)

Carey, S. Warren (ed.) THE EXPANDING EARTH. Proceedings of an International Symposium. University of Tasmania, $1983,423 \mathrm{p} ., \$ 27.50$ Aus. Available from University of Tasmania, Department of Geology, Hobart, Tasmania 7001, Australia.

Gade, Herman G. et al. (eds.) COASTAL OCEANOGRAPHY, Proceedings of an Institute held in Norway. NATO Confernce Series IV, vol. 11. Plenum, 1983, 590p., \$79.50 (U.S.A., Canada); $\$ 95.40$ (elsewhere). (25)

Glaseser, Phyllis S. (ed.) DATA FOR SCIENCE AND TECHNOLOGY. Proceedings of the 8 th inter national CODATA Conference held October 1982 , Jachranka, Poland. North-Holland, 1983, 350p., 549 (U.S.A., Canada); Dfl. 125 (elsewhere). (14)

INDUSTRIAL MINERALS, Special Liaison Report of Workshop held September-October 1981, Kingston, Jamaica. Commonwealth Geological Liaison Office, 1983, 27p., price not listed. Available from Commonwealth Geological Liaison Office, Marlborough House, Pall Mall, London SWIY SHX, U.K.

Kuo, J.T. EARTH TIDES. Proceedings of 9 th International Symposium, held August 1981, New York City. Schweizerbart'sche Verlagsbuchinandlung, $1983, \$ 38.27(\mathrm{H}) .(27)$

Medaris, L.G., Jr. et al. (eds.) PROTEROZOIC GEOL OGY: Selected Papers from an International Pro terozoic Symposium. GSA Memoir 161, 1983 $318 \mathrm{p} ., \$ 49(\mathrm{H}) .(16)$

Pepin, R.O. and $\mathrm{O}^{\prime}$ Connell, R.J. VolATILES. Technical conference report. LPI, 1983, 207p., \$3 (U.S.A.); $\$ 9.50$ (others, air mail). (19)

Ponnamperuma, Cyril (ed.) COSMOCHEMISTRY AND THE ORIGIN OF LIFE. Proceedings of an Institute held June 1981, Maratea, Italy, NATO Advanced Study Institutes Series C, vol. 101. Reidel, 1983 $386 \mathrm{p}$, \$63. Available from Kluwer Boston, 160 Old Derby Street, Hingham, MA 02043, U.S.A.

PRIMERA CONFERENCIA LATINOAMERICANA DE ROCA FOSFORICA, Resumenes de Trabajos Tecnicos, held October 1983, Cochabamba, Bolivia 1983, 88p., no price listed. Available from V. Ricaldi, Casilla 193, Cochabamba, Bolivia.

Schenk, Paul E. et al. (eds.) REGIONAL TRENDS IN THE GEOLOGY OF THE APPALACHIANCALEDONIAN-HERCYNEAN-MAURITANIDE OROGEN. Proceedings of NATO Advanced Study Institute held August 1982, New Brunswick, Canada. Reidel, 1983, 420p., price not listed. (13)

Schneider, Hans-J. (ed.) MINERAL DEPOSITS OF THE ALPS AND OF THE ALPINE EPOCH IN EUROPE. Proceedings of the 4th ISMIDA held October 1981 Bavaria, F.R.G. Special Publication No. 3, Society for Geology Applied to Mineral Deposits. SpringerVerlag, 1983, 402p., \$42.50. (29)

SHORELINE PROTECTION. Proceedings from Symposium held in Britain. Thomas Telford, 1983 208p., £ $26.50(\mathrm{H})$. (32)

Street-Perrott, A., Beran, M., and Ratcliffe, R. (eds.)
VARIATIONS IN THE GLOBAL WATER BUDGET Symposium held 1981, Oxford, U.K. Reidel, 1983 518 p., price not listed. (13)

Suess, Erwin and Thiede, Jörn (eds.) COASTAL UPWELLING, Part A: Responses of the Sedimentary Regime to Present Coastal Upwelling. (see also Thiede and Suess) NATO Conference Series IV, vol. 10a. Conference held September 1981, Vilamoura, Portugal. Plenum, 1983, 604p., \$85.(25)

Taylor, G.J. WORKSHOP ON LUNAR BRECCIAS AND SOILS AND THEIR METEORITIC ANALOGS. LPI, 1982, 172p., \$3 (U.S.A.); $\$ 8.50$ (others, air mail). (19)

Thiede, Jörn and Suess, Erwin (eds.) COASTAL UPWELLING, Part B: Sedimentary Records of Ancient Coastal Upwelling. NATO Conference Series IV, vol. 10b. Conference held September 1981, Vilamoura, Portugal. Plenum, 1983, 610p., $\$ 84 .(25)$

VERY LONG BASELINE INTERFEROMETRY TECHNIQUES. Papers from an International Conference held August/September 1982, Toulouse, France. Most papers in English. 1983, 488p., 250FF. Avail able from Cepadues Editions, 111 rue NicolasVauquelin, 31000 Toulouse, France.

Walker, D. and MCCallum, I.S. WORKSHOP ON MAGMATIC PROCESSES OF EARLY PLANETARY CRUSTS: Magma Oceans and Stratiform Layered Intrusions. LPI, 1982, 234p., \$3 (U.S.A.); \$9.50 (others, air mail). (19)

Wong, C.S. et al., (eds.) TRACE METALS IN SEA WATER. Proceedings of an Institute held in Erice, Italy. NATO Conference Series IV, vol. 9. Plenum, 1983, 934p., \$115 (U.S.A., Canada); \$138 (elsewhere). (25)

Yen, T.F. et al. (eds.) CHEMICAL AND GEOCHEMICAL ASPECTS OF FOSSIL ENERGY EXTRACTION. Papers from a Symposium held August 1980 in Las Vegas U.S.A. Ann Arbor Science, 1983, 266p., \$37.50.(10)

\section{NEW REFERENCE VOLUMES}

1983 DIRECTORY OF NORTH AMERICAN GEO SCIENTISTS ENGAGED IN MATHEMATICS, STATISTICS AND COMPUTER APPLICATIONS, Mathematical Geologists of the United States, 1983 146p., \$10. Available from John C. Davis, Geologic Research Section, Kansas Geological Survey, The University of Kansas, Lawrence, KS 66045, U.S.A.

Glut, Donald F. THE NEW DINOSAUR DICTIONARY. Citadel, 1983, 288p., \$21.95. Available from Citadel Press, Dept. D-3, 120 Enterprise Avenue, Secaucus, NJ 07094 , U.S.A.

Gusev, B.V., Zefirov, N.N., Petukhov, A.S. and Kupalov-Yaropolk, I.R, ENGLISH-RUSSIAN DICTIONARY OF APPLIED GEOPHYSICS. Pergamon, 1983, 488p., price not listed. (24)

Ridge, J.D. (ed.) ANNOTATED BIBLIOGRAPHIES OF MINERAL DEPOSITS IN EUROPE, Part 1: Northern Europe, including examples from the U.S.S.R. in both Europe and Asia. Pergamon, 1983, 780p., price not Jisted. (24)

Tomkeieff, S.I. DICTIONARY OF PETROLOGY Wiley, 1983, 1,500p., \$84.95. (36)

van der Spoel, S. and Heyman, R.P. A COMPARATIVE ATLAS OF ZOOPLANKTON. SpringerVerlag, 1983, 186p., \$49.50.(29)

\section{MISCELLANEOUS}

Harland, W.B., Cox, A., Llewellyn, P.G., Pickton, C.A.G., Smith, A.G., and Walters, R. WALLCHART FOR A GEOLOGIC TIME SCALE. Cambridge, 1983 $1000 \times 600 \mathrm{~m}$, rolled $84.95+V A T$ in UK/\$8.95. (11) 


\section{For Your Bookshelves}

\section{NEW MAPS AND ATLASES}

ATLAS OF AUSTRALIAN RESOURCES, 3 maps: (1) Australia, coal resources 1981; (2) Australia, energy resources 1981 ; (3) Australia, surface rock types. Division of National Mapping, 1982, scale: 1:10000000, prices not listed. Available from Map Sales, Box 31, Belconnen, A.C.T. 2616, Australia.

Bosse, Heinz-Richard et al. KARTE DER BUNDES REPUBLIK DEUTSC̄HLAND. Bundesanstalt fÜ Geowissenschaften und Rohstoffe, 1982, scale: 1:1000000. I map and 19-page text, price not listed (7)

Chang, W.Y. (Chief compiler) THE MARINE AND CONTINENTAL TECTONIC MAP OF CHINA AND ITS ENVIRONS. English edition. Science Press, 1983, scale: 1:15000000, $\$ 66.70$. Available from Science Press, 137 Chaoyangmennei Dajie Street, Beijing, People's Republic of China.

GEOLOGICAL MAP OF SWAZILAND. Directorate of Overseas Surveys (Great Britain), 1982, scale: 1:250 000, price not listed. Available from Geological Survey and Mines Department, Box 9, Mbabane, Swaziland; or E. Stanford Ltd., 12/14 Long Acre, London WC2E 9LP, U.K.

Imai, Isao and Isshiki, Naoki et al. GEOLOGICAL MAP OF JAPAN. Geological Survey of Japan, 1982 scale: 1:5000000, I sheet. Available from Geological Survey of Japan, 1-3, Higashi 1-chome, Yatabernachi, Tsukuba-gun, Ibaraki-ken, 305 Japan.

Ishihara, Takemi. FREE AIR GRAVITY ANOMALY MAP OF THE CENTRAL PACIFIC. Marine Geology Map Series 19. Geological Survey of Japan, 1982, scale: 1:2000000, price not listed. Available from Geological Survey of Japan, 1-3 Higashi 1-chome, Yatabemachi, Tsukuba-gun, Ibaraki-ken, 305 Japan.

Kron, Andrea and Stix, John. GEOTHERMAL GRAD IENT MAP OF THE UNITED STATES EXCLUSIVE OF ALASKA AND HAWAII. Los Alamos Nationa Laboratory, 1982, 2 sheets, scale: 1:2500000, \$10 (folded); \$12 (flat). (22)

Kubicki, Stanislaw and Ryka, Waclaw (eds.) GEOLOGICAL ATLAS OF CRYSTALLINE BASEMENT IN POLISH PART OF THE EAST-EUROPEAN PLATFORM, Contribution to IGCP Project 86, East-European Platform (SW Border). Geologica Institute, 1982, 24p. and 24 tables/maps, price not listed. In Polish, Russian and English. Available from Instytut Geologiczny, Ul. Rakowiecka 4, 00 975 Warszawa, Poland.

LES ANCIENNES MINES DU MAROC (de la Prèhistoire au xixéme siecle). Service géologique du Maroc, 1982, scale: 1:2000000, price not listed. (8)

MAPA GEOLOGICO DE COSTA RICA (edicion preliminar). Ministerio de Economia e Industria, 1982, scale: 1:200000, 9 sheets, price not listed. Available from Direccion de Geologia, Minas y Petroleo, Ministerio de Economia e Industria, Apartado 10216, San José, Costa Rica.

NATIONAL SOIL MAP, England and Wales. Soi Survey of England and Wales, 1983, 6 sheets, scale: 1:250000, atlas set 23. Available from Publications Officer, Soil Survey of England and Wales, Rothamsted Experimental Station, Harpenden, Herts. AL 5 2JQ, U.K.

Saadi, Moussa. CARTE MINIERE ET ENERGETIQUE DU MAROC. Service Géologique du Maroc, 1982, scale: 1:2000000, price not listed (8)

Saadi, Moussa. CARTE STRUCTURALE DU MAROC. Service Géologique du Maroc, 1982, scale: 1:2000000, price not listed. (8)

SEISMICITY MAP OF MIDDLE AMERICA. U.S. GEOlogical Survey, 1983, scale: 1:8000000, \$5 (folded); $\$ 10$ (rolled). (22)

Tucholke, Brian E., Houtz, Robert E., and Ludwig, William J. MAPS OF SEDIMENT THICKNESS AND DEPTH TO BASEMENT IN THE WESTERN NORTH ATLANTIC OCEAN BASIN. Two-map set and 16- page text, (map scale: one inch equals one degree longitude), \$16.(1)

LIST OF PUBLISHERS

(1) AAPG Bookshore, P.O. Box 979, Tulsa, OK 74101, U.S.A.

(2) Academic Press, Inc., 111 Fifth Avenue, New York, NY 10003, U.S.A.; or $24 / 28$ Oval Road, London NWI 7DX, U.K.; or P.O. Box 300, North Ryde, NSW 2113, Australia.

(3) Allen \& Unwin, Inc., 9 Winchester Terrace, Winchester, MA 01890, U.S.A; or P.O, Box 18 , Park Lane, Hemel Hempstead, Herts. HP2 4TE, U.K.

(4) American Geophysical Union, 2000 Florida Avenue, NW, Washington, DC 20009, U.S.A

(5) Birkhauser Boston, Inc., 380 Green Street, P.O. Box 2007, Cambridge, MA 02139, U.S.A.

(6) Blackwell Scientific Publications, ASR Marketing Booksellers, 31 Bridge Street, Berkhamsted, Herts. HP4 2EB, U.K.; or 52 Beacon Street, Boston, MA 02108, U.S.A.; or 99 Barry Street, Carlton, Vic. 3053, Australia.

(7) Bundesanstalt für Geowissenschaften und Rohstoffe, Stilleweg 2, 3000 Hannover 51, F.R.G.

(8) Bureau des Echanges - Direction de la Géologie, Ministére de l'Energie et des Mines, RabatChellah-Morocco.

(9) Bureau de Recherches Géologiques et Minières, Division Edition et vente, B.P. 6009, 45060 Orleans Cedex, France.

(10) Butterworth, Tower Office Park, Woburn, MA 01801 , U.S.A.

(11) Cambridge University Press, The Pitt Building, Trumpington Street, Cambridge CB2 IRP, U.K.; or 32 East 57 th Street, New York, NY 10022 U.S.A.; or 296 Beaconsfield Parade, Middle Park, Melbourne 3206, Australia.

(12) Columbia University Press, 136 South Broadway, Irvington-on-Hudson, NY 10533, U.S.A.

(13) D. Reidel Publishing Company, 479-483 Voorstraat, Box 17, 3300 AA Dordrecht, The Netherlands; or 190 Old Derby St., Hingham, MA 02043, U.S.A.

(14) Elsevier Scientific Publishing Inc., 52 Vanderbilt Avenue, New York, NY 10017, U.S.A.; or P.O. Box 211, 1000 AE Amsterdam, The Netherlands; or D. A, Book Depot Pty. Ltd., II 13 Station Street, Mitcharn, Vic. 3132, Austraia.

(15) Gebrüder Borntraeger D-7000 Stuttgart I, Johannestrasse 3A, F.R.G.; or Lubrecht \& Cramer, Route 42 and Forestburgh Road, RFD 1, Box 227, Monticello, NY 12701, U.S.A.

(16) Geological Society of America, Publication Sales, P.O. Box 9140, Boulder, CO 80301 , U.S.A.

(17) Geophysical Press, Brouwersgracht 236, 1013 HE Amsterdam, The Netherlands.

(18) IHRDC Publications, 137 Newbury Street, Boston, MA 02116 , U.S.A.

(19) Lunar and Planetary Institute, 3303 NASA Road One, Houston, TX 77058, U.S.A.

(20) McGraw-Hill Book Co., 1221 Avenue of the Americas, New York, NY 10020, U.S.A.

(21) Methuen, 733 Third Avenue, New York, NY 10017 , U.S.A.

(22) NOAA/NGDC, 325 Broadway, Boulder, CO 80303 , U.S.A.

(23) Oxford University Press, Walton Street, Oxford OX2 6DP, U.K.; or 16-00 Pollitt Drive, Fair Lawn, NJ 07410 , U.S.A.
(24) Pergamon Press, Maxwell House, Fairview Park, Elmsford, NY 10523, U.S.A.; or Headington Hill Hall, Oxford OX3 OBW, U.K.; or P.O. Box 544, Potts Point, NSW 2011, Australia.

(25) Plenum Publishing Corp., 233 Spring Street, New York, NY 10013, U.S.A.; or $88 / 90$ Middlesex Street, London EI 7EZ, U.K.

(26) Princeton University Press, 41 William Street, Princeton, NJ 08540, U.S.A.

(27) E. Schweizerbart'sche Verlagsbuchhandlung (Nägele u. Obermiller), Johannesstrasse 3A, D7000 Stuttgart 1, F.R.G.

(28) Soviet Geophysical Committee, USSR Academy of Sciences, Molodezhnaya, 3, Moscow, GSP-1, U.S.S.R.

(29) Springer-Verlag New York Inc., 175 Fifth Avenue, New York, NY 10010 , U.S.A.

(30) Superintendent of Documents, U.S. Government Printing Office, Washington, DC 20402, U.S.A.

(31) Theophrastus Publications S.A., 33 J. Theologou Str., Zographou, Athens 622, Greece.

(32) Thomas Telford Ltd., 1-7 Great George Street, London SWIP 3 AA, U.K.

(33) University of Tokyo Press, 7-3-1 Hongo, Bunkyo-ku, Tokyo 113, Japan.

(34) Van Nostrand Reinhold Company Inc., 135 West 50th Street, New York, NY 10020, U.S.A.

(35) Westview Press, 5500 Central Avenue, Boulder, CO 80301 , U.S.A.

(36) John Wiley \& Sons, inc., 605 Third Avenue, New York, NY 10158, U.S.A.; or Baffins Lane, Chichester, Sussex POI9 IUD, U.K.
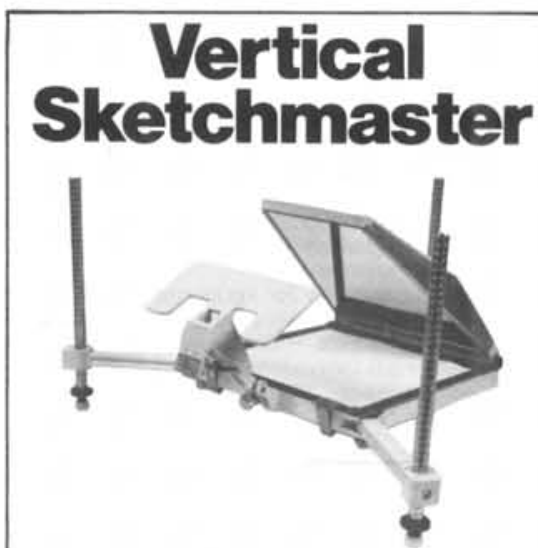

Designed for transferring detail from aerial photographs to a map sheet or from one drawing or map to another, the $260 \mathrm{GE}$ Vertical Sketchmaster is an outstanding instrument that has become the standard of the industry. Constructed of the finest materials under rigid quality control, the 260GE can be used in normal lighting conditions. It comes with a case and fourteen diopter lenses are optional accessories for a wide selection of scale changes.

Write for Free Catalog of Stereoplotting Instruments

Alan Gordon Enterprises Inc. 5362 Cahuenga Boulevard North Hollywood, CA 91601 Telephone: (213) 985-5500 